\title{
Industrial upgrade, economic catch-up and industrial policy in Brazil: general trends and the specific case of the mining industry
}

Upgrade industrial, catch-up econômico e política industrial no Brasil: tendências gerais e o caso específico da mineração

\author{
Renato Garcia (1) \\ Ulisses Pereira dos Santos (2) \\ Wilson Suzigan ${ }^{(1)}$ \\ (1) University of Campinas \\ (2) Federal University of Minas Gerais
}

\begin{abstract}
The aim of this paper is to analyze the role of industrial policy in promoting technological upgrading in Brazil. To do that, we focus on the main characteristics of the Brazilian national innovation system and the role of its institutions. We examine whether industrial policy implemented between 2003 and 2014 was able to promote changes in agents' conventions towards more vigorous strategies linked to technological upgrading and catchup. In addition, we analyze the Brazilian mining industry, a sector in which Brazil has developed relevant competitive advantages in international markets, and in which domestic agents have built important operational capabilities. Main results show the huge difficulties faced by industrial policy efforts in establishing mechanisms to drive technological catchup, based on the unsuccessful experiences of policies in the years 2002 to 2014 . The specific experience of the Brazilian mining industry confirms these general findings, since domestic mining companies were not able to create new technological capabilities, even during the commodity price boom period.
\end{abstract}

\section{Keywords}

Industrial Policy, institutions, knowledge and innovation, mining.

JEL Codes O31, O33, O38.

\section{Resumo}

O objetivo deste artigo é analisar o papel da política industrial na promoção da upgrading tecnológica no Brasil. Para isso, nós focalizamos nas principais características do sistema nacional de inovação no Brasil e no papel das instituições. Nós examinamos se a política industrial implementada entre 2003 e 2014 foi capaz de promover mudanças nas convenções dos agentes em direção a estratégias mais vigorosas ligadas ao catch-up tecnológico. Ainda, nós analisamos a mineração, um setor em que o Brasil desenvolveu vantagens competitivas relevantes nos mercados internacionais, e no qual os agentes nacionais construiram importantes capacitações operacionais. Os principais resultados mostram as enormes dificuldades enfrentadas pelos esforços da política industrial em estabelecer mecanismos voltados para o catch-up tecnológico, a partir das experiências frustradas das políticas nos anos de 2002 a 2014. A experiência específica da mineração confirma esses resultados gerais, uma vez que as mineradoras nacionais não foram capazes de criar novas capacitações tecnológicas, mesmo durante o periodo de boom dos preços das commodities.

\section{Palavras-chave}

Politica Industrial, instituições, conhecimento e inovação, mineração.

Códigos JEL O31, O33, O38. 


\section{Introduction}

Since the beginning of this new century, we have seen the revival of industrial policy in several developed and developing countries. Similarly, in Latin America, the revival of industrial policy took place after a decade in which it was necessary to overcome the existing anti-industrial policy bias. Several countries have made efforts to redesign a set of measures pursuing technological upgrade and economic catch-up (Devlin; Moguillansky, 2013; Schneider, 2015; Suzigan; Furtado, 2006). In Brazil, this effort to revitalize industrial policy began in the early 2000s, with the launch of the PITCE - Industrial, Technological and Foreign Trade Policy (Suzigan; Garcia; Assis Feitosa, 2020). Several measures were taken to create new incentives for industrial activities and technological development, seeking to encourage private agents to increase their innovative efforts and to implement new technological capabilities.

However, the effort to promote industrial policy in Brazil was thwarted by the characteristics of the national innovation system. In general, we can see overall low levels of $R \& D$ expenditures, quite concentrated $n$ the public sector; very low levels of private $\mathrm{R} \& \mathrm{D}$ expenditures, and private firms' innovation strategies, all of which are mainly based on the purchasing of capital goods; low levels of patenting; and the strong presence of Multinational Companies in the productive structure. In this perspective, industrial policy was not able to modify the main conventions established among private agents, in order to establish new development conventions (Erber, 2012). This means that the industrial policy effort faced strong institutional shortcomings, ranging from the difficulty in establishing and coordinating development programs, up to obstacles in converging it with macroeconomic policies.

The case of mining illustrates these difficulties to a great extent. Even though presenting low technological opportunities, the mining industry in Brazil has been able to accumulate several skills and operational capabilities along its trajectory. This allowed firms to achieve important competitive advantages in the international markets. During the 2000s, both the commodity price boom and the revival of industrial policy could have been catalyzing forces in a broader and more autonomous process of building new technical and technological capabilities in the Brazilian mining industry. However, industrial policy measures were not able to create 
incentives to internalize these skills. In addition, mining firms were facing a variety of growing problems in the environmental area, with two large dam breaks during the 2010s.

Based on this context, this paper aims to assess the role of industrial policy in promoting technological upgrading in Brazil. We present our analysis at two different levels. First, we analyze the level of general industrial policy in Brazil during the period of 2003-2014. Secondly, we discuss the specific case of the mining industry in Brazil. We show that industrial policy efforts to foster technological upgrade and catch-up have not been able to change the private convention toward a wider and more ambitious strategy for accumulating industrial technological skills, especially through the increase of the private R\&D expenditures. Furthermore, in the specific case of mining, even during the commodity pricing boom, domestic companies were also not successful in accumulating technological capabilities, especially in the supplier industries which are the main drivers of the technological innovation in mining. Nevertheless, the growth in production has led to the aggravation of environmental problems, with two large dam breaks in the last years.

The paper has five sections. Section Two presents the basic characteristics of the Brazilian National System of Innovation, and the institutional background for industrial policy in Brazil. Section Three provides a brief description of main industrial policy measures in the period of 2003-2014. Section Four presents the sectoral cut for mining industry in Brazil, discussing the main technological issues and the policies to strengthen sectoral capabilities. Finally, Section Five presents final remarks.

\section{Economic catch-up and policy in the Brazilian Inno- vation System}

\subsection{Fundamental Characteristics of the Brazilian Innovation System}

The National Innovation System is an important notion and a valuable reference for the analysis of technological dynamics and economic catchup in different countries. The National Innovation System approach was widely used to analyze how its main components interact with themselves in order to foster innovation. The main assumptions of this approach are 
that firms absorb ideas from suppliers, users, and institutions of knowledge, and that innovation requires huge interactions with several different kinds of agents (Chaminade; Lundvall; Haneef, 2018).

Despite the wide use of the approach to analyze technology dynamics, there are some important limits for the use of the notion of National Innovation System in developing countries, and, especially, in Latin America (Albuquerque, 2007; Niosi, 2010; Rapini et al., 2009). The most important reason for this limitation is the presence of less developed economic and environments in developing countries. In developing countries, there is a lack of private players and public institutions which can support development strategies based on innovation. For this reason, National Innovation System in developing countries is usually referred to as "immature innovation systems" (Albuquerque, 2007; Rapini et al., 2009). Immature innovation systems are characterized by a set of institutions which involves business firms, universities and research centers, financial institutions, and educational and training systems. But, they are limited in nature, weak and have serious flaws.

Previous studies have shown that levels of $R \& D$ expenditures in Brazil are on the overall low (Table 1), as well are the levels of patenting (Brito-Cruz; Mello, 2006; Limoeiro; Schneider, 2019). Besides the low total $\mathrm{R} \& \mathrm{D}$ expenditures, the levels of private $\mathrm{R} \& \mathrm{D}$ expenditures are even lower, since a high share of the total expenditure came from the public sector (Figure 1). The private $\mathrm{R} \& \mathrm{D}$ expenditures are quite low, averaging close to $0.5 \%$ of GDP during the 2000 s and up to 2014 . In 2012, government accounted for $28 \%$ of the total R\&D expenditures, while the participation of the public higher education was $27 \%$ and private firms was $45 \%$ (Limoeiro; Schneider, 2019; Suzigan; Garcia; Assis Feitosa, 2020). Among business firms, Multinational Companies (MNC) have a huge presence in the manufacturing sector, and they accounted for around half of private $\mathrm{R} \& \mathrm{D}$ expenditures; while Stated-Owned Enterprises (SOE), such as the Brazilian Oil Company Petrobras, accounted for another large share. Scientists work largely in the public sector, especially in public universities, and just $26 \%$ of scientists work for the private sector - in comparison to South Korea, where $80 \%$ of scientists work for private business firms (Brito-Cruz; Mello, 2006). 
Table 1 Research and development as share of GDP in East Asia and Latin America, 2000-2010

\begin{tabular}{lrrr}
\hline Country/region & $\mathbf{2 0 0 0}$ & $\mathbf{2 0 1 0}$ \\
\hline East Asia* & 1.1 & 1.7 \\
\hline China & 0.9 & 1.8 \\
\hline Indonesia & 0.1 & 0.1 \\
\hline Korea & 2.3 & 3.7 \\
\hline Malaysia & 0.5 & 1.1 \\
\hline Singapore & 1.9 & 2.1 \\
\hline Taiwan & 2.0 & 2.9 \\
\hline Thailand & 0.3 & $\mathrm{Na}$ \\
\hline Latin America* & 0.4 & 0.5 \\
\hline Argentina & 0.4 & 0.6 \\
\hline Brazil & 1.0 & 1.2 \\
\hline Chile & na & 0.4 \\
\hline Colombia & 0.1 & 0.2 \\
\hline Costa Rica & 0.4 & 0.5 \\
\hline Mexico & 0.4 & 0.5 \\
\hline
\end{tabular}

Source: Limoeiro e Schneider (2019); with data from World Bank, World Development Indicators. *unweighted averages.

Figure 1 Private R\&D expenditures rate as a share of GDP - Brazil, 2001-2014 (in percentage)

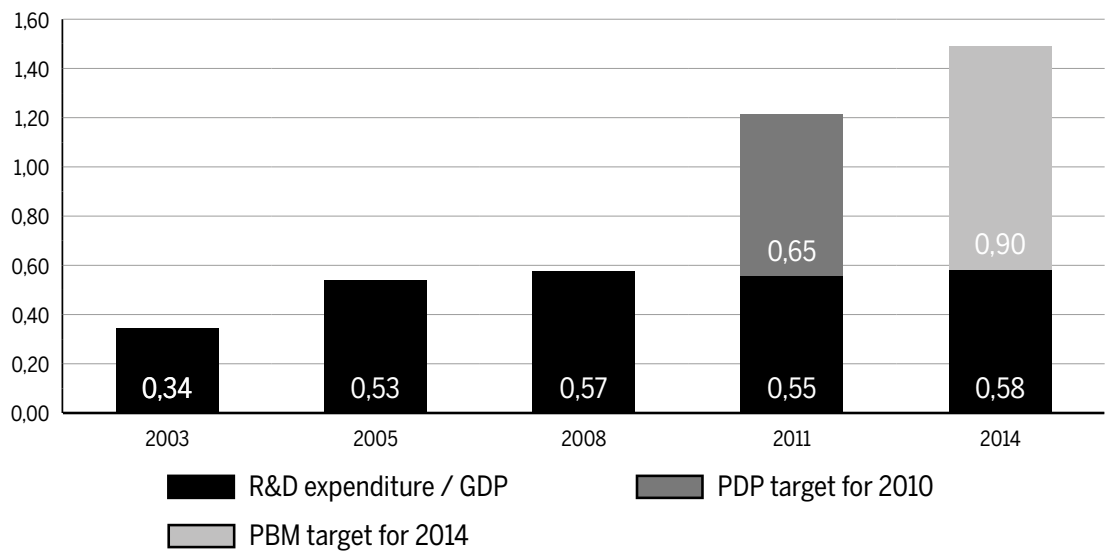

Source: Suzigan et al. (2019). Data from IBGE-PINTEC, 2003; 2005; 2008, 2011; 2014. 
The weakness of private firms' innovation efforts is a key characteristic of the Brazilian National System of Innovation. MNC account for half of private $\mathrm{R} \& \mathrm{D}$ expenditures, and they dominate most of the high-tech sectors, such as electronics, chemicals, as well as the automotive sector. The main exception is the aircraft manufacturing industry. However, as a share of revenues, $\mathrm{MNC}$ expend less for $\mathrm{R} \& \mathrm{D}$ than Brazilian domestic companies. On the other hand, among the largest business domestic firms, most of them are diversified business groups, in sectors such as natural resources, financial services and retail. The largest Brazilian business groups have virtually no R\&D expenditures (Limoeiro; Schneider, 2019). Despite the small amount of $\mathrm{R} \& \mathrm{D}$ expenditures, a large share of Brazilian firms surveyed by the Brazilian Innovation Survey (called Pintec) have adopted innovation, whether product or process innovations, or innovations for the firm or for the market. However, most of those innovations refer to equipment renewal or to the launching of products originally developed abroad.

For this reason, innovation in Brazil has long been state driven. Several cases of success are behind some public institution, or a deliberate policy effort (Brito-Cruz; Mello, 2006). The large share of public R\&D expenditure, the policy incentives for innovation and the role of SOE show the crucial role played by the state in supporting innovation in Brazil. Links between public research institutes and universities explain many of the successful cases of Brazilian firms participation in the international markets (Suzigan; Albuquerque, 2011). In addition, the rise role of public research universities is resulting in the increase of the academic output, and, at the same time, providing new insights for strengthening engagement with industry (Garcia et al., 2019). Finally, SOE such as Petrobrás (Oil and Gas) and Embrapa (agricultural research), and former SOE such as Vale (mining) and Embraer (aircraft manufacturing) play a crucial role in the Brazilian Innovation System. They account for a large share of firms' R\&D expenditures in Brazil, even in low and medium-tech sectors. In addition, SOE were widely instrumental in the industrial policy initiatives in Brazil during the 2000s up to 2015.

\subsection{Industrial policy and institutions}

The characteristics of the Brazilian system of innovation reinforce the cru- 
cial role of industrial policy in fostering innovation and economic catchup. The huge shortcomings of the innovation system in Brazil, especially regarding the low levels of private $\mathrm{R} \& \mathrm{D}$ expenditure, reveal that industrial policy needs to assume a central role in the development of incentives to increase the innovation effort in general. In many countries, industrial policy has been increasing its importance in fostering innovation and economic upgrading, even though the term, industrial policy, was not used widely (Andreoni; Chang, 2019). Many developing countries, especially in Asia, have extensively used industrial policy strategies to foster technological catch-up. In Europe and in the US economic planning and industrial policy are the main strategies to reconstruct the productive and manufacturing foundations of their economies. In Brazil, the beginning of the 2000s marked the revival of industrial policy. After a period of strong anti-industrial policy bias during the 1990s, several measures of industrial policy were launched in Brazil in order to foster innovation and catch-up (Kupfer; Ferraz; Marques, 2013; Suzigan; Furtado, 2006).

In our view, industrial policy should be defined in a wide sense, including both industry-specific policy measures, and more general strategies which affect industrial performance, such as technological and macroeconomic policies (Chang, 1994; Suzigan; Villela, 1997). Even though we recognize the existence of various notions of industrial policy, we must highlight its role in fostering innovation and structural change (Cimoli; Dosi; Stiglitz, 2009). Based on this broad definition of industrial policy and with the assumption that there is a strong relation between innovation and development, we emphasize the ability of industrial policy to affect the system of rules and the economic signaling, in order to foster private firms' innovative behavior (Suzigan; Garcia; Assis Feitosa, 2020). This approach is theoretically founded in the assumption that innovative behavior, in addition to strictly economic signals and private incentives, is embedded in scientific institutional, and public-policy contexts (Dosi, 1988). It is in line with the perspective that economic activities in general require the involvement of physical and social technologies, which implies some type of coordinating mechanism to ensure that the several aspects of these activities are satisfactorily performed (Nelson, 2008). Changes in physical technologies are accessible, and are considered encouraging, only if social technologies can be adapted to exploit them effectively. Social technologies have a strong influence on the way physical technologies 
evolve. Therefore, it may be useful to think that social and physical technologies co-evolve (Nelson; Sampat, 2001).

The assumption that economic activities are embedded in a process of co-evolution of physical and social technologies reveals the role played by institutions. Institutions are usually defined as the "rules of the game" (Hodgson, 2006; Nelson, 2008). We can be more specific, considering the coexistence of different types of institutions, and examine these shared mental models in terms of conventions. Conventions is conceptually defined as socially shared systems of rules of thought or behavior (Dequech, 2017; Hodgson, 2006). These rules indicate what (not) to do in certain circumstances. Thus, they affect how private agents and policymakers interpret their environment, economic signaling, and how they act in economic contexts. When the notion of convention is perceived in terms of development, it can involve some issues, such as fiscal and monetary policy, growth and inflation, exchange rate regime, state intervention in the economy, and technological change (Erber, 2004). An addition of this notion also perceives them as shared mental building blocks that drive choices and shape the evolution of an economic system. In this way, we argue that industrial policy is a key factor to interfere and to foster a development convention. In this development convention, actions of private agents are guided from a socially shared system of rules (Dequech, 2017; Erber, 2012). Policy measures ought to have the ability to affect existing conventions in order to encourage innovative behavior and structural change. They also must determine targets for both individual firms and aggregate domestic technological indicators. This set of targets can play a key role in giving new signals and guides to private firms, in order to be able to intercede in the prevailing convention (Erber, 2012; Suzigan; Garcia; Assis Feitosa, 2020).

This paper assumes that institutions play a crucial role in shaping the set of incentives and the structure of economic signaling for private agents. Institutional mechanisms can shape economic conventions, which in turn can drive the behavior of private agents and may (or may not) lead to deliberate efforts toward economic development and technological catch-up. In this sense, we analyze the recent effort of industrial policy in Brazil, based of the issues related to the institutional problem. Thus, we discuss to what extent the measures of industrial policy in Brazil, in the last two decades, have been able to establish a clear structure of signaling to private agents, 
in order to stimulate them to establish a development convention. This analysis is applied to two different contexts. First, we analyze the general efforts of industrial policy in Brazil since the beginning of the 2000s in fostering technological upgrade and catch-up. Second, we put a magnifying glass on a specific case of mining in Brazil. This industry has shown excellent economic and productive performance in the last decades, since it has been able to achieve new technical and productive capabilities, even in a sector with low technological opportunities.

\section{Industrial policy for technological catch-up in Brazil}

\subsection{PITCE (2003-2007) and the emergence of a new convention}

The first initiative of the revival of industrial policy in Brazil was made in the beginning of the 2000s, with the launch of the Industrial, Technological and Foreign Trade Policy (PITCE). The PITCE was launched in 2003 with its main challenge to overcome the anti-industrial policy bias which prevailed during the 1990s. This initiative tried to encourage the emergence of an alternative convention based on increasing efforts toward innovation and technological catch-up. The program presented some noteworthy advances in the coordination of strategic actions of the government and of private agents aiming at the development of capabilities linked to technological change (Suzigan; Garcia; Assis Feitosa, 2020). The emphasis on manufacturing was a vital signal to domestic firms toward the creation and diffusion of technical progress. Important industrial policy instruments were also launched during this period, such as the Innovation Law (2004) and the Law of Good (2005), both of them focused on the granting of tax incentives as a counterpart to the increase in $\mathrm{R} \& \mathrm{D}$ expenditures and other innovative activities (Rocha, 2015). However, the main shortcoming for the industrial policy effort was the macroeconomic policy, that still had as its priority the maintenance of inflation targets. The main instruments of macroeconomic policy conflicted with the measures created toward fostering industrial and technological activities (Nassif; Bresser-Pereira; Feijó, 2017).

These industrial policy initiatives played a key role in decreasing the informational gap, and in the reduction of private agents' uncertainty, such as the above-mentioned instruments linking incentives to the accomplish- 
ment of industrial policy goals. Additionally, there was also a great number of organizations and innovation-funding programs (Suzigan; Garcia; Assis Feitosa, 2020). Overall, these initiatives represented an attempt to drive a new and alternative convention among government and private sector, focused on fostering innovation and technological catch-up. However, the main attempts to guide this alternative convention faced strong difficulties, since social technologies are very stable over time (Nelson, 2008; Nelson; Sampat, 2001). The legacy of the 1990s was the extinction of programs and mechanisms of industrial policy, together with a lack of capabilities within policy institutions, including public policy-making agencies, with growing difficulties with regard to any action aimed at industrial and technological development. Previous macroeconomic policy was maintained in the prevailing system of rules, which could damage most efforts related to learning and to the building of new capabilities (Cimoli; Dosi; Stiglitz, 2009). The poor coordination mechanisms between short-term macroeconomic policy and long-term industrial and technological policies largely explains the weak results (Nassif; Bresser-Pereira; Feijó, 2017). We can also point out shortcomings in the implementation of policy measures, especially connected to the lack of articulation between the main instruments and the demands of private firms, the vulnerability of the economic infrastructure, the insufficiencies of the ST\&I system, and the fragility of the central command and coordination of the whole process (Suzigan; Furtado, 2006).

\subsection{PDP (2008-2010) and the difficulty in establishing a new con- vention}

The second step for the resurgence of industrial policy in Brazil was the so-called "Productive Development Policy" (PDP), launched in 2008, during a particularly good domestic economic environment. General main macroeconomic variables were presenting good results: the GDP was increasing; trade balance constraints were resolved; fiscal debt was reduced; there had been remarkable improvements in income distribution. Public policy was committed to maintaining economic growth with the intention of sustaining the cycle of expansion for the domestic economy, mainly by creating mechanisms and incentives to boost aggregate investment (Kupfer; Ferraz; Marques, 2013). The new policy tried to cover macroeconomic goals, as 
well as sectoral targets for almost all Brazilian industrial sectors. Setting goals was an attempt to guide new conventions by enhancing coordination with private agents, reducing information gaps and uncertainty, as well as ensuring the legitimacy of the policy (Suzigan; Garcia; Assis Feitosa, 2020).

The industrial policy chose a broad, comprehensive, and ambitious range of 25 priority sectoral industries. These options contributed to an enhanced perception of uncertainty about policy direction and economic signaling, which reduced the coordination capacity of strategic government actions. It represented a setback in preserving the convention that had been previously created, mainly because it neglected innovation as a key driver of the industrial strategy. Industrial policy went back to its traditional way, which meant the intensive use of subsidies and mechanisms of protection against international competition (Devlin; Moguillansky, 2013; Suzigan; Furtado, 2006). Furthermore, several industrial policy measures were short-term orientated, with very few actions driven toward innovation and technological catch-up (Suzigan; Garcia; Assis Feitosa, 2020). Many policy measures and programs were designed to provide responses to the potential negative effects of the 2009 international financial crisis.

This signal was quickly captured by the private sector, which oriented its strategies in the direction of the use of compensatory policies with a great rent-seeking character and without significantly enhancing R\&D expenditures and innovation efforts. The Brazilian Development Bank (BNDES) became the main executor of industrial policy, and it strongly expanded its budget for investment funding, but with few new funding measures towards interactive learning and technical change. Policy abandoned its orientation toward the fostering of new private $R \& D$ expenditures with very few tries to diversify investment portfolios. In addition, industrial policy was not effective in promoting additionality in private R\&D expenditures (Colombo; Cruz, 2018; Rocha, 2015), maintain its low capacity to foster interactive learning and structural change. In fact, policy actions were excessively concentrated on promoting and supporting industrial investment rather than on innovation and technological catch-up.

In this way, PDP was not able to present itself as a superior alternative to the prevailing system of rules. During this period, we have not seen improvements in the agents' ability of coordination towards innovation (Suzigan; Garcia; Assis Feitosa, 2020). Thus, we can assume that there was a failure of the policy to reduce uncertainty for private agents, due 
to changes in the focus of industrial policy, which occasioned in losses of its legitimacy. Additionally, even with the changes of the macroeconomic and international scenario, macroeconomic policy remained in conflict with the main goals of industrial policy and technological catch-up (Nassif; Bresser-Pereira; Feijó, 2017).

\subsection{Brasil Maior Plan (2011-2014) and prevailing convention lock-in}

The economic scenario after 2008 was quite unpromising, with increasing interest rates, appreciated exchange rates, decrease of manufacturing production, with no signs of a setback in the short-term. In this environment, the Brazilian government launched the Brasil Maior Plan, aiming to reiterate the role of the state as regulator, prime-mover, guide, and fosterer of economic growth and technological catch-up. This program presented larger and more audacious targets, comparing with former programs. However, same main orientation was kept, largely based in instruments such as tax exemption of investment, exports and innovation expenditures (Suzigan; Garcia; Assis Feitosa, 2020). An important orientation of the new plan was intensification in the use of instruments to support innovation and technological catchup, such as public procurement policy; tax relief on employment in manufacturing; expansion of commercial safeguards; creation of new BNDES programs for investments and for innovation; budget boost for innovation for Finep (the Brazilian Innovation Agency); improvements in the legal framework toward fostering innovation; and the creation of a new industry-applied research organization, called the Brazilian Agency for Industrial Research and Innovation (EMBRAPII) (Suzigan; Garcia; Assis Feitosa, 2020).

This set of measures to boost private capital expenditures as well as innovation were accompanied by measures to protect the domestic industry and stimulate manufacturing, due to the diagnosis of the crisis in the international market, which would require specific policies to maintain the manufacturing activities. However, some of the same old problems are present in the new program, such as a weak orientation toward innovation, specially with regards to private sector. The abandonment of innovation as a guiding strategy for industrial policy increased the difficulties to establish a new convention due to a growing perception of uncertainty, hindering coordination and failing in rescue of the government legitimacy. 
The small effectiveness of the sectoral instances has also contributed to decrease the legitimacy. This decision-making dispersion generates informational and coordination differences and was also a common characteristic of the previous industrial policies analyzed (Suzigan; Garcia; Assis Feitosa, 2020). Finally, we can conclude that Brasil Maior Plan represented a continuity of the previous policy efforts and, therefore, it failed to produce changes in the prevailing system of rules and conventions.

\section{Mining industry in Brazil: production growth versus technological progress}

\subsection{Growth in production of iron ore}

Mining has been a central activity in the Brazilian economy since its origins in the $18^{\text {th }}$ century. After a long process of industrialization, although the country had not reached technological maturity, the mining industry was quite well developed and completely inserted in the international market. The technical and productive evolution in the sector during the second half of the $20^{\text {th }}$ century allowed Brazil to take advantage of an extremely favorable scenario in the international market starting in the late 1990s and the early 2000s. The increase in commodity prices in the international market, mainly due to the effect of the increased Chinese demand, was one of the main drivers of growth in the sector. This allowed the mining industry to take full advantage of one of the main drivers of Brazilian economic growth in this period (Libânio, 2008): investments aimed at expanding production capacity having reached record levels since then. However, as of 2010, the reduction in economic growth rates in China, the consequent slowdown in the demand for mineral goods in the international market and the change in the price trajectory led to the end of the expansion cycle (Mesquita; Carvalho; Ogando, 2016).

Brazil is one of the worldwide iron ore top producers, responsible for almost $20 \%$ of the global output, ranking at the second place in 2018. This position is a result of the massive exploitation of the local reserves. Vale S.A. is the world largest producer of iron ore and the third largest mining company in the world (Mining Global, 2020). The company's share in the Brazilian production of iron ore is over $70 \%$ (BLUNDI et al., 2019). So, 
the results of Brazilian production of iron ore are highly correlated to the performance of Vale.

The trajectory of Brazilian mining industry during the 2000s shows the huge expansion in both production and exports (Figure 2). Over the period, the annual average growth in the production of iron ore was $4.57 \%$, leading the production to rise from 212.5 million tons to 454 million tons, in 2017. This growth performance was due to the international market procurement from 2000 , leading exports to increase $6.72 \%$ on average per year. Consequently, the share of exports in the total production had risen from $55 \%$, in 2000 , to $77 \%$, in 2017 .

Figure 2 Production and exports of iron ore in Brazil. 2000 - 2017 (millions of tons)

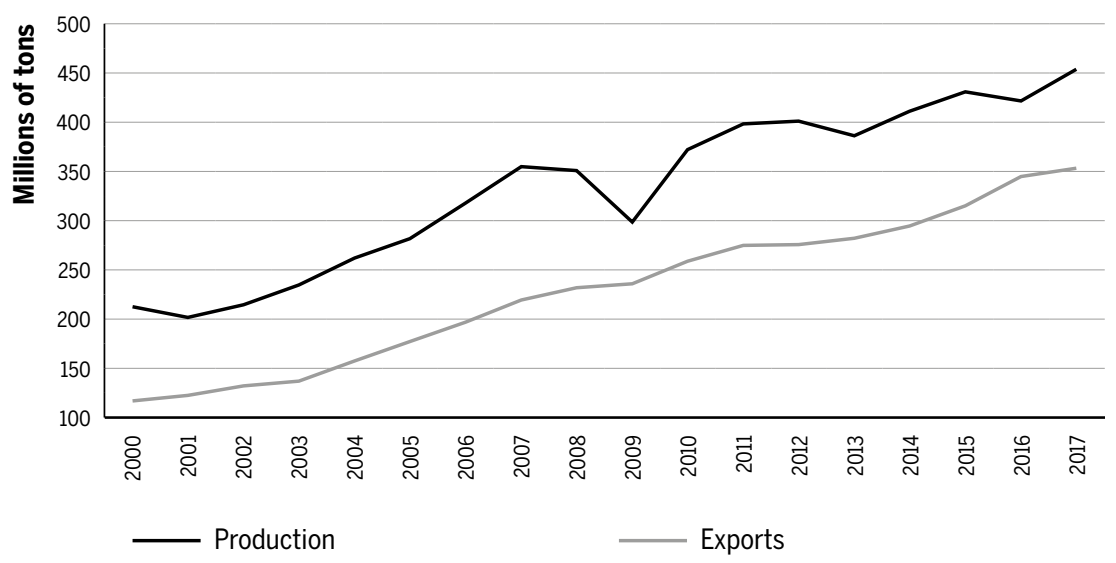

Source: Brazilian Mining Agency.

The importance of the exports for Brazilian iron ore production exposes the dependence of the sector on the international market movements. In this sense, we can see how the 2008 crisis affected domestic production (Figure 2) which, although it did not generate immediate impacts on external sales, it caused a slowdown in the growth of iron ore exports. It is noteworthy that it is precisely from this period that the Chinese economy reduces its growth rates (Mesquita; Carvalho; Ogando, 2016). The growth trajectory of iron ore mining in Brazil lead also to an expansion in the sector's employment, which increases $6.6 \%$ per year during the same period (Table 2). The employment and production data bring some light on the expansion in the sector over the analyzed period. 
Table 2 Number of employees in iron ore mining in Brazil - 2000-2017

\begin{tabular}{lr|r}
\hline Years & Number of Employees & $\begin{array}{r}\text { Compound Annual Growth Rate - } \\
\text { CAGR (\%) }\end{array}$ \\
\hline $\mathbf{2 0 0 0}$ & 16,283 & \\
\hline 2005 & 26,669 & 10.37 \\
\hline $\mathbf{2 0 1 0}$ & 37,462 & 7.03 \\
\hline $\mathbf{2 0 1 5}$ & 50,257 & 6.05 \\
\hline $\mathbf{2 0 1 7}$ & 48,292 & -1.97 \\
\hline CAGR & & 6.60 \\
\hline
\end{tabular}

Source: Brazilian Ministry of Labour.

\subsection{Technological dynamics of mining industry in Brazil}

Mining is an industry with reduced technological opportunities, which means that it presents little propensity to innovation, especially for products (Figueiredo et al., 2017). Most of the technological developments aim at improving manufacturing processes, or establish organizational changes. A large share of innovation in mining come up from specialized suppliers, mainly from heavy machinery, equipment and specialized services (Daly; Valacchi; Raffo, 2019). In order to understand the technological dynamics of mining, its technological progress is derived mainly from spillovers from other industries, which present their own technological trajectories, which are not directly aligned to mining.

During the $20^{\text {th }}$ century, technological progress in mining was derived from innovations in heavy transport technologies, especially in tractors and trucks, drilling machines, and others. Many technology developers for mining were originally suppliers for other sectors, such as agriculture, lumber exploitation and construction. Nowadays, one important driver of technical advance in mining is automation (Mesquita; Carvalho; Ogando, 2016). The development of sensors, autonomous equipment, and vehicles has contributed to bring the sector closer to the establishment of the "intelligent mining". The adoption of these technologies is decisive for competitiveness, even when their development was not directly dependent on in-house firms' R\&D expenditures.

Most technological trends in mining came from developed countries, such as Japan and United States. Such progress is concentrated especially 
in countries with structured and diversified innovation systems, where technological advances in transport, equipment and information technologies are found. On the other hand, countries with large productive capacity in mining, but narrow innovation systems, are not able to take part in this innovative approach. This is the case of Brazil, Chile and South Africa, since they are large producers of mineral goods, but they do not present good innovation indicators for mining (Daly; Valacchi; Raffo, 2019), due to their lack of industrial diversification.

The Brazilian mining industry is highly dependent on international suppliers, especially those engaged in more advanced technologies. As a consequence, the country's share in world technological indicators for the sector is quite small: data from WIPO shows that the Brazilian share in the world total mining patents is less than 1\% (Daly; Valacchi; Raffo, 2019). The productive specialization and interactions between industry and universities were not sufficient for leading the country to achieve high technological performance in mining. The reduced accumulated skills and capabilities in the Brazilian mining industry is due to the under developed production chain, which was not able to incorporate specialized suppliers domestically (Figueiredo et al., 2017). Some evidence for this statement is that more than $90 \%$ of the patent applications in mining technology in Brazil during the period of 2000 to 2015, which involves mining equipment, technology, and service suppliers, are from abroad (Blundi et al., 2019). The lack of industrial diversification put several constraints on the internalization of technological opportunities, even in a sector in which Brazil plays a relevant role in the international market.

Even if the main technical advances are concentrated in innovation from suppliers, in-house R\&D expenditures by mining companies can still play an important role, especially for decoding and adapting technologies that were developed in other sectors. In addition, the mining industry faces local-specific technological challenges, such as, those related to geological, climatic, legal or environmental elements, which demand specific solutions. Because of this, one should expect that the growth in mining should induce an increase in the sector's R\&D expenditures. This trend was observed for some mining countries during the 2000s; such as, Australia, the largest producer in the world, where expenses in innovation and $R \& D$ significantly rose in that period (Blundi et al., 2019). 
In Brazil, innovation and technical progress played only a small part of the total capital expenditures of local firms in the period of 2010-2012: the last data on investments in the Brazilian Mineral Yearbook (Table 3). Investments are broken down into those planned for mines and those for iron ore processing plants. In both cases, most of the resources planned were directed towards the acquisition or repairing of equipment. Technological innovations in the mines represented $1.4 \%$ of investments and in the case of the plants only $2.27 \%$.

Table 3 Main Expected Investments in Iron Ore Mining - Brazil, 2010-2012

\begin{tabular}{lrrr}
\hline & Mines & Manufacturing \\
\hline Geology and mineral research & 2.59 & - \\
\hline Infrastructure & 9.36 & 15.74 \\
\hline Technological Innovation and systems & 1.39 & 2.27 \\
\hline Aquisition or repare of equipment & 58.36 & 54.20 \\
\hline Environment & - & 1.86 \\
\hline Others & 28.30 & 25.94 \\
\hline Total & 100.00 & 100.00 \\
\hline
\end{tabular}

Source: Brazilian Mining Agency.

With regard to technological trends based on patent applications in the Brazilian mining industry, the main focus has been on mineral processing (refining) and transportation and logistics (Blundi et al., 2019), which infers that domestic and multinational mining companies' technological efforts have been driven by the reduction of costs and the increase of productivity. This technological trend is in line with market movements and with the growth in competitiveness in the sector, in which competition is mainly based on operation scale gains and efficiency in production. The result helps in the understanding of the outstanding expansion in production and exports of iron ore during the 2000s. Meanwhile, policies aimed at internalizing equipment and service suppliers for improving innovation in mining were not effective (Figueiredo et al., 2017).

Those aspects suggest that, even in the face of a huge growth in production and exports, technological dynamics in mining was driven to absorb technical spillovers from other sectors mainly through the acquisition of equipment. Innovation in Brazilian mining was mainly driven to process improvements and cost reduction. Nevertheless, the increase in produc- 
tion brought a range of problems and needs that demanded greater technological efforts which were not taken, since innovation attracted only a small part of the budgeted investments in the sector.

\subsection{Growth and technology dependence in Brazilian mining}

Innovation in mining is strongly related to technological progress in other industries, such as, machinery, automation equipment, and software. Consequently, most of the technology developed for mining applications is not developed in major mining exporting countries, but in mining suppliers of machinery and technology providing countries (Daly; Valacchi; Raffo, 2019). Consequently, most of the innovation does not take into account local-specific problems and needs.

In Brazil, the development of a mining related industry was narrow and based on the presence of multinational corporations. Even though the level of revenues and investments in mining were propitious to induce the development of related industries, efforts to internalize strategic suppliers were not effective. The rise in demand for machinery, equipment and specialized services was met mostly by imports from foreign suppliers. Therefore, the Brazilian mining industry has lost opportunities to diversify its industrial base taking advantage of the income differential of the period of accelerated growth (Figueiredo et al., 2017). In many advanced economies, the growth in mining exports lead to a surge of related industries, specialized in providing equipment, machinery, and technologies. This is the case of countries like US, Germany, Sweden, and Norway, where mining related industries developed and reached the status of technology exporters. In other cases, opportunities have risen for the provision of specialized services for mining activities. In countries such as Australia and Canada, small and medium knowledge-intensive firms have been successful in contributing to the development of local mining exploitation (Furtado; Urias, 2013).

A different trend was observed in Brazil, even after the resurgence of industrial policies in the beginning of the century. Those policies were not successful in supporting the emergence of strategic suppliers and technology providers during the rise of commodities exports. In this way, while the country strengthened its position as a major mining producer and ex- 
porter, the dependence on technologies developed abroad remained. Technology developments in mining equipment, technology and services in Brazil are dominated by non-resident companies (Table 4). Foreign companies are responsible for almost all patent applications on technologies related to mining in Brazil. This is a clear consequence of the failure in the promotion of further changes in the Brazilian industrial system for capturing opportunities derived from the growth in exporting sectors.

Table 4 Lead mining equipment, technology and service patent applicants in Brazil, 2000-2015

\begin{tabular}{lrr}
\hline Company & Country & \% Patents \\
\hline Nippon Steal & Japão & 17,07 \\
\hline Mitsubishi & Japão & 10,83 \\
\hline Du Pont & US & 6,66 \\
\hline Outotec & Finland & 5,30 \\
\hline ThyssenKrupp & Germany & 5,05 \\
\hline Summitomo Metal & Japão & 3,97 \\
\hline Honey Well & US & 3,19 \\
\hline Caterpillar & US & 2,41 \\
\hline Sin Tokogio & Japão & 2,36 \\
\hline SMS Siemag & Germany & 1,89 \\
\hline Total & & 58,73 \\
\hline
\end{tabular}

Source: Blundiet al. (2019).

Conversely, international experience shows the importance of the establishment of a domestic industrial base for mining development and innovation. Through these experiences, the machinery suppliers overtook the mining industry in the exports over the years. Consequently, those countries are still relevant in mining technology developments, while local mining exploitation has lost its relative importance.

Despite of the entry barriers in the heavy machinery and equipment industries, changes in the mining exploitation and management have favored the appearance of opportunities for smaller and knowledge intensive firms. Software development and consultancy in mining projects have been incorporated into the economic structure of traditional mining countries; such as, Australia and Canada (Furtado; Urias, 2013). In this way, the adoption of information and communication technologies by mining 
activities resulted in opportunity windows for newcomers. Some experiences show how a natural resource-based activity might favor the rise of technology and capital-intensive activities, if opportunities are identified and taken. We believe that one of the roles of industrial policy is precisely mapping those opportunity windows related to changes in technological trajectories and build local capabilities to take advantage of them.

Another aspect on this trend towards technological dependence in mining innovation is related to the lack of local-specific oriented problem solving. In resource-based economies, technological efforts should be directed to reduce its negative impacts on environment and society. Mining is an economic activity that generates many negative externalities over its surrounding areas, such as air pollution, intensive use of water and the increase in the traffic of heavy transport vehicles. Because of this, the rise of specialized service providers and consultants, or an in-house technology developer is particularly important, since those problems vary from country to country, and also region to region. In Brazil, specifically, the main negative result of growth in mining activities concerns the volume of mine waste generated by the sector ${ }^{1}$. From 1996 to 2005, 766 million tons of iron ore waste were generated in Brazil and, from 2010 to 2019, it was estimated to reach to 1.9 billion tons (Silva; Viana; Cavalcante, 2012) ${ }^{2}$. Two-and-a-half times more waste was produced in the country by the end of the 2000s than that observed between 1996 and 2005, as a result of the growth in production during the boom of the commodities prices (Figure 3).

In face of this scenario, the new challenge is related to how to deal with the growing amount of mine waste derived from the expansion in mining. The most used way to dispose of this waste is in dams (Coelho et al., 2017). Such dams are often built using the tailings themselves, that are stacked to contain a slurry of water and iron ore waste. Because of this, these mine waste dams are the most flexible and low-cost option for companies, since usually they have available the necessary physical space. They allow quick

1 The mining activity generates two main types of solid waste, the sterile one that results from the extraction of the mineral good and the tailings, which originates from its processing (Silva; Viana; Cavalcante, 2012). The tailings, which form a kind of mud, are usually deposited in containment dams in the care of mining companies.

2 In the projection made by Silva and colleagues, they considered only the production of tailings resulting from the processing of the ore. Sterile and other kinds of waste related to mining activities were not included. 
responses from the firms to the production growth cycles, since the expansion of such structures only require the continuity in the stacking of mine waste to make them higher (Silva; Viana; Cavalcante, 2012).

Figure 3 Estimated production of iron ore tailings in Brazil - 2010-2030

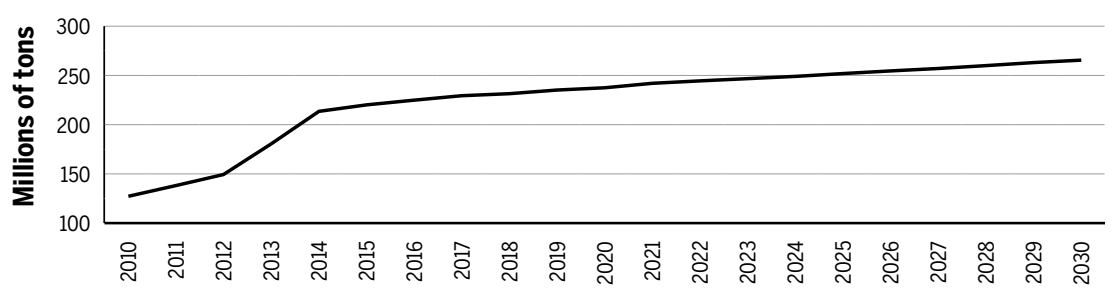

Source: Silva, Viana e Cavalcante (2012).

The construction of such dams and their expansion involve many environmental costs, due to the need for large territorial areas for their installation and the very polluting nature of the materials deposited in them. Another externality related to the presence of mining dams is related to the risks of collapse, threatening human, animal and plant lives in their surrounding areas. In this sense, the growth of mining production should consider strategies to reduce possible social and environmental damages related to such activity. These costs and risks have gained publicity from the two large dam failures occurred in Mariana in 2015, and in Brumadinho, in 2019, both traditional mining cities in Brazil. However, the environmental and human disasters are not so rare in the history of the Brazilian mining, which registered many dam failures since the 1980s (Coelho et al., 2017). Consequently, forecasting the increase in the risks related to the expansion of dams in the country should not be that difficult.

In terms of public policy, efforts were not put in place to change the pattern for the use of dams, although many alternative technologies to substitute them, or to minimize their impacts, were known. Dry methods for iron extraction and technologies to avoid dams have been adopted by companies worldwide, and also in Brazil. However, the costs and time demanded for converting previously established plants to these substitutive technologies were obstacles, since the expansion in existing dams always presented the easiest alternative. In the lack of a regulatory standard, or an enforcement policy, companies were not motivated to adopt different 
technologies for replacing iron ore waste dams. So, even when the companies experienced a huge growth in prices and revenues, investments for changing this pattern of waste disposal were not put in place, although the technologies for shortening the use of dams is available. Therefore, even though, new technologies for waste disposal rather than in dams were available, they were not adopted by companies in view of the small incentive to change the established model. Only after the disaster in Brumadinho, changes in regulatory requirements for waste dams changed in Brazil. The Brazilian regulatory mining agency prohibited the use of mining waste dams in Brazil and established the replacement of these disposal methods in all of the mining areas in the country (Brasil, 2019).

A sectorial and innovation policy could encourage companies to revert part of their revenues obtained during the mining boom to the search and application of technological solutions on this issue. Defining a strategy for technological development driven by the reduction, or the recycling, of the mine waste in Brazil seems to be becoming a reality as a state policy mission. Only after major tragedies and after the rise in prices and revenues in mining, the state considered the need of changing this pattern of production.

Meanwhile, technological developments aimed at the reuse of mining waste in Brazil have been carried out by universities and were available at the time of the recent dam failures. The R\&D focused on this purpose was observable especially in those universities located in mining and metallurgical areas (Carmignano, 2020). The use of mine waste in other economic activities, such as construction or agriculture, with technologies developed by universities, arises as a possible way for dealing with this challenge reducing the use of dams. Even so, the lack of companies' involvement and the absence of equipment, technology and service suppliers within the country suppressed the possible uses of those technologies by private sector.

\section{Final remarks}

Brazilian industrial policy can be understood as comprised of two different moments. In the first phase, policy was driven toward inducing changes in the behavior of firms, which led to the emergence of an alternative 
convention based on a growing innovative effort in aggregate terms. In the following phase, this policy became less than effective and resulted in a gradual return of the prevailing convention, explained by the recurrence of a constant relationship between innovative activities and economic performance. The proposed framework reveals that there are three main reasons for this exhaustion of the policy: a) a change in strategic orientation toward innovation, which increased informational differences and the perception of uncertainty; b) an increasing difficulty in coordinating agents; and c) low legitimacy of policies. Therefore, an alternative system of rules, despite the results achieved, has increasingly failed to present itself as superior to the prevailing convention.

Institutional problems revealed themselves as important forces that prevented industrial policy from reaching its main objective of increasing private $\mathrm{R} \& \mathrm{D}$ expenditures in Brazil and, thus, providing a broader process of building technical capabilities and technological upgrading and catchup in Brazilian industry. We can verify these failings in several ways such as the lack of a domestic, private manufacturing sector and in the intragovernmental difficulties in promoting the convergence of the industrial policy efforts with the macroeconomic objectives.

We can clearly see these institutional shortcomings when examining the experience of the Brazilian mining industry in the last two decades. Policy actions toward the mining industry have failed to take advantage of the commodities price boom to drive investments for creating new technical and technological capabilities in the Brazilian mining industry. Production and exports of mining products experienced a huge growth, but technological dependence on foreign companies, specially suppliers of machinery goods and services, remained. Consequently, opportunities for strengthening the Brazilian mining supply-chain, embodying equipment, technology, and service suppliers, were lost. The innovative performance in mining is still narrow in Brazil, while major competitors are investing in the building of greater and advanced capabilities to their local mining industry. In addition, the absence of enforcement toward further technical change during the mining growth period, allowed the maintenance of an obsolete and dangerous strategy for mining waste disposal, resulting in irreparable costs after the two major disasters with dam failures in the last few years. Mining is a particularly good example of a resource-based activity that has a great potential to induce the development of related indus- 
tries and services. However, industrial policy in Brazil was not effective in capturing the favorable opportunities to do that in the last two decades.

\section{References}

ALBUQUERQUE, E. D. M. E. Inadequacy of technology and innovation systems at the periphery. Cambridge Journal of Economics, v. 31, n. 5, p. 669-690, 10 jan. 2007.

ANDREONI, A.; CHANG, H.-J. The political economy of industrial policy: Structural interdependencies, policy alignment and conflict management. Structural Change and Economic Dynamics, v. 48, p. 136-150, mar. 2019.

BLUNDI, D. et al. Technology appropriation and technology transfer in the Brazilian mining sector. Geneva: WIPO, 2019.

BRITO-CRUZ, C. H. DE; MELLO, L. DE. Boosting Innovation Performance in BrazilOECD Economics Department Working Papers. Paris: [s.n.]. Disponível em: <http://search.ebscohost. $\operatorname{com} /$ login. aspx ? direct $=$ true $\& \mathrm{db}=\mathrm{buh} \& \mathrm{AN}=28746133 \& \operatorname{login}$ age $=$ Login . asp\&site $=$ ehost-live $>$.

CHAMINADE, C.; LUNDVALL, B.-Å.; HANEEF, S. Advanced introduction to national innovation systems. Cheltenham: Edward Elgar Publishing, 2018.

CHANG, H.-J. The political economy of industrial policy. London: Macmillan, 1994.

CIMOLI, M.; DOSI, G.; STIGLITZ, J. Industrial policy and development: The political economy of capabilities accumulation. New York: Oxford University Press, 2009.

COELHO, M. C. N. et al. Regiões Econômicas Mínero-Metalúrgicas e os Riscos de Desastres Ambientais das Barragens de Rejeito no Brasil. Revista da Anpege, v. 13, n. 20, p. 83-108, 2017.

COLOMBO, D. G.; CRUZ, H. N. DA. Impacts of the Brazilian innovation tax policy on the composition of private investments and on the type of innovation. Revista Brasileira de Inovação, v. 17, n. 2, p. 377-414, 5 set. 2018.

DALY, A.; VALACCHI, G.; RAFFO, J. Mining patent data: Measuring innovation in the mining industry with patentsWorld Intellectual Property Organization (WIPO) Economic Research Working Paper. Geneva: [s.n.].

DEQUECH, D. The Concept of Development Conventions: Some Suggestions for a Research Agenda. Journal of Economic Issues, v. 51, n. 2, p. 285-296, 3 abr. 2017.

DEVLIN, R.; MOGUILLANSKY, G. What's new in the new industrial policy in Latin America? In: STIGLITZ, J. E.; LIN, J. Y. (Eds.). The industrial policy revolution I. London: Springer, 2013. p. 276-317.

DOSI, G. Institutions and markets in a dynamic world. The manchester school, v. 56, n. 2, p. 119-146, 1988.

ERBER, F. S. Innovation and the Development Convention in Brazil. Revista Brasileira de Inovação, v. 3, n. 1, p. 35, 17 ago. 2004. 
ERBER, F. S. The evolution of development conventions. Revista de Economia Contemporânea, v. 16, n. 1, p. 1-22, abr. 2012.

FIGUEIREDO, P. N. et al. Acumulação de capacidades tecnológicas, inovação e competitividade industrial: alguns resultados para a Indústria Brasileira de MineraçãoTechnological Learning and Industrial Innovation Working Paper Series. Rio de Janeiro: FGV, 2017. Disponível em: $<$ http://bibliotecadigital.fgv.br/ojs/index.php/tlii-wps/article/view/65738>.

FURTADO, J.; URIAS, E. Recursos naturais e desenvolvimento: estudos sobre o potencial dinamizador da mineração na economia brasileira. São Paulo: IBRAM-Instituto Brasileiro de Mineração, 2013.

GARCIA, R. et al. How the Benefits, Results and Barriers of Collaboration Affect University Engagement with Industry. Science and Public Policy, v. 46, n. 3, p. 347-357, 1 jun. 2019.

HODGSON, G. M. What Are Institutions? Journal of Economic Issues, v. 40, n. 1, p. 1-25, 4 mar. 2006.

KUPFER, D.; FERRAZ, J. C.; MARQUES, F. S. The return of industrial policy in Brazil. In: STIGLITZ, J. E.; LIN, J. Y. (Eds.). The industrial policy revolution I. London: Springer, 2013. p. 327-339.

LIBÂNIO, G. O crescimento da China e seus impactos sobre a economia mineira. Revista Economia \& Tecnologia, v. 4, n. 2, 2008.

LIMOEIRO, D.; SCHNEIDER, B. R. Institutions, politics, and state-led innovation. In: REYNOLDS, E. B.; SCHNEIDER, B. R.; ZYLBERBERG, E. (Eds.). Innovation in Brazil: Advancing Development in the 21st Century. New York: Routledge, 2019.

MESQUITA, P. P. D.; CARVALHO, P. S. L. DE; OGANDO, L. D. Desenvolvimento e inovação em mineração e metais. BNDES Setorial, 2016.

MINING GLOBAL. Top 10 Global Mining Companies. Mining Global, 2020. Available in: https://www.miningglobal.com/top10/top-10-global-mining-companies. Accessed in October 20, 2020.

NASSIF, A.; BRESSER-PEREIRA, L. C.; FEIJÓ, C. The case for reindustrialisation in developing countries: towards the connection between the macroeconomic regime and the industrial policy in Brazil. Cambridge Journal of Economics, v. 42, n. 2, p. 355-381, 2017.

NELSON, R. R. What enables rapid economic progress: What are the needed institutions? Research Policy, v. 37, n. 1, p. 1-11, 2008.

NELSON, R. R.; SAMPAT, B. N. Making sense of institutions as a factor shaping economic performance. Journal of Economic Behavior \& Organization, v. 44, p. 31-54, 2001.

NIOSI, J. Building National and Regional Innovation Systems. Cheltenham: [s.n.].

RAPINI, M. S. et al. University-industry interactions in an immature system of innovation: evidence from Minas Gerais, Brazil. Science and Public Policy, v. 36, n. 5, p. 373-386, 1 jun. 2009.

ROCHA, F. Does governmental support to innovation have positive effect on R\&D investments? Evidence from Brazil. Rev. Bras. Inov., v. 14, p. 37-60, 2015.

SCHNEIDER, B. Designing industrial policy in Latin America: Business-state relations and the new developmentalism. New York: Springer, 2015. 
SILVA, A. P. M. DA; VIANA, J. P.; CAVALCANTE, A. L. B. Diagnóstico dos Resíduos Sólidos da Atividade de Mineração de Substâncias Não Energéticas Relatório de Pesquisa IPEA. Brasilia: [s.n.].

SUZIGAN, W.; ALBUQUERQUE, E. M. The underestimated role of universities for the Brazilian system of innovation. Revista de Economia Política, v. 31, n. 1, p. 03-30, 2011.

SUZIGAN, W.; FURTADO, J. Política Industrial e Desenvolvimento. Revista de Economia Politica, v. 26, n. 2(102), p. 163-185, 2006.

SUZIGAN, W.; GARCIA, R.; ASSIS FEITOSA, P. H. Institutions and industrial policy in Brazil after two decades: have we built the needed institutions? Economics of Innovation and New Technology, v. 0, n. 0, p. 1-15, 6 fev. 2020.

SUZIGAN, W.; VILLELA, A. V. Industrial policy in Brazil. Campinas: Universidade Estadual de Campinas Instituto de Economia, 1997.

\section{About the authors}

Renato Garcia-rcgarcia@unicamp.br

Institute of Economics, University of Campinas, Campinas, SP, Brazil.

ORCID: https://orcid.org/0000-0001-9739-1658.

Ulisses Pereira dos Santos - ulisses@cedeplar.ufmg.br

Centro de Desenvolvimento e Planejamento Regional, Universidade Federal de Minas Gerais, Belo Horizonte, MG, Brasil. ORCID: https://orcid.org/0000-0002-6912-0479.

WilsonSuzigan-wsuzigan@unicamp.br

Department of Science and Technology Policy, Institute of Geosciences, University of Campinas, Campinas, SP, Brazil. ORCID: https://orcid.org/0000-0002-2193-4756.

The authors would like to thank Eduardo Albuquerque, Marcelo Pinho and Marcia Rapini, and other participants at the Belo Horizonte and Diamantina Workshops 2019; and two anonymous referees; all of them provided useful comments on an early version of this manuscript. Usual disclaimers apply.

\section{About the article}

Submission received on May 23, 2020. Approved for publication on September 08, 2020. 